\title{
Biochemical predictors of short term mortality in elderly residents of chronic care institutions
}

\author{
JEAN WOO, S M CHAN, Y T MAK, ${ }^{*}$ R SWAMINATHAN* \\ From the Departments of Medicine and *Chemical Pathology, The Chinese University of Hong Kong, Shatin, \\ New Territories, Hong Kong
}

SUMMARY A survey of 208 elderly subjects living in four long term care institutions was undertaken over three months to identify nutritional and other variables that could be used to predict mortality during the subsequent three months. There were 58 men (mean age (SD) 75.6 (9.6) years) and 150 women (79.5 (8.4) years). Twenty nine subjects died (12 men and 17 women) within three months of completing the study. Twenty eight out of 57 variables differed significantly between those who died and those who survived. Subjects who died had lower systolic blood pressure, poorer intake of protein calories, lower concentrations of haemoglobin, plasma retinol, zinc, total cholesterol, and higher albumin adjusted plasma calcium concentrations. Stepwise regression analysis identified five variables that predicted mortality: plasma fructosamine; transferrin; glycosylated haemoglobin; prealbumin; and haemoglobin. The sensitivity, specificity, and predictive values of the discriminant function score using 0 as the demarcation between survivors and non-survivors were $75 \%, 97 \%$, and $95 \%$, respectively. This score could therefore be used to identify those most in need of nutritional support.

Malnutrition is a well recognised problem among elderly subjects in long term care, often as a result of deficient intake of proteins ${ }^{1-2}$ as well as vitamins. ${ }^{3}$ Protein calorie malnutrition, in particular, predisposes to morbidity and mortality and may be unrecognised due to its insidious onset. ${ }^{1}$ Measurements useful in identifying protein calorie malnutrition include those of thyroxine-binding prealbumin and retinol binding protein, ${ }^{4-5}$ albumin, transferrin, urinary creatinine and creatinine/height index, total lymphocyte count, measurement of delayed cutaneous hypersensitivity reactions, and anthropometric indices. ${ }^{6}$ Many of these indices have been examined with a view to determining the predictors of the development of complications such as sepsis or mortality. ${ }^{7-14}$ Prognostic indices were different in different studies, probably reflecting the different nature of the populations studied. Only the studies by Rudman et al specifically examined elderly residents of long term care institutions. In a nutritional survey of elderly subjects living in chronic care institutions, anthropometric, haematological, and biochemical indices giving a total of 57 variables were examined to determine the best predictors of short term mortality in this population.

Accepted for publication 27 July 1989

\section{Patients and methods}

Between December 1987 and February 1988, a survey was undertaken of residents of four chronic care institutions in Hong Kong. All 157 residents from two institutions were studied; 51 others living in the other two institutions had been referred by doctors from the Prince of Wales Hospital. Residents had either been referred by relatives, social workers, or doctors, and came from all areas of Hong Kong. They had various degrees of dependency and may or may not have had chronic disease. The survey was performed by one of the authors (JW) and a registered nurse, after having obtained informed consent from as many of the subjects as possible wherever feasible. Information was collected on the diagnosis which resulted in institutional care, coexisting diseases, length of stay, functional ability, and use of drugs. All anthropometric measurements were performed by the nurse. Arm circumference was measured at the mid-point between the acromion and olecranon process. Skinfold thickness of biceps and triceps were measured with Holtain calipers at the same point. The average of three readings taken was used. Height and weight could not be measured in a large number of subjects as they were bedridden. Blood pressure was measured in 
the supine position, using a mercury sphygmomanometer.

A fasting specimen of urine was collected for determination of urinary electrolytes, creatinine, and hydroxyroline. Venous blood $(20 \mathrm{ml})$ was drawn from an antecubital vein between 9-11 am for estimation of complete blood count, renal and liver function tests, calcium, phosphate, urate, glucose, glycosylated haemoglobin, fructosamine, total thyroxine, prealbumin, retinol binding protein, transferrin, ferritin, folic acid, cyanocobalamin, retinol, beta carotene, red blood cell thiamine transketolase (TK), glutathionine reductase (GTR) and aspartate aminotransferase (AST) activities, ascorbic acid, vitamin E, 25 hydroxy vitamin D (25 OHD), copper and zinc.

Complete blood count was performed on a Technicon H-6000 haematology analyser (Technicon, Instruments Co, Tarrytown, New York, USA). Routine urine and biochemical tests were performed on a multichannel Parallel Analyzer (American Monitor Corporation, Indianna, USA). Urinary hydroxyproline in acid hydrolysate was measured by a colorimetric reaction with dimethylaminobenzal- dehyde after chloramine $T$ oxidation on a centrifugal analyser (Cobas Bio, Roche Diagnostic, Basel, Switzerland). An aliquot of plasma was stored at $-70^{\circ} \mathrm{C}$ for batch assay of $250 \mathrm{HD}$ by a competitive protein binding method using plasma from vitamin D deficient pigs at a dilution of 1 in 4000 after extraction with acetonitrile. ${ }^{15}$ Plasma calcium concentration was corrected for plasma albumin concentration according to the method of Payne et al. ${ }^{16}$ Total thyroxine was measured by a Syva EMIT kit (Syva Co, Palo Alto, California, USA) automated on a Cobas Bio centrifugal analyser. Cyanocobalamin, folic acid, and plasma ferritin concentrations were estimated by a radioimmunoassay method using kits from Diagnostic Products Corporation (Los Angeles, California, USA). Plasma copper and zinc were measured by flame atomic absorption spectrophotometry after protein precipitation with trichloroacetic acid. ${ }^{17}$ Cholesterol assay was performed with an enzymatic kit from Baker Instrument, Allentown, Pennsylvania, USA automated on an Encore centrifugal analyser from the same company. Measurement of glucose, glycosylated haemoglobin, and fructosamine have

Table 1 Some characteristics of residents in long term care institutions

\begin{tabular}{|c|c|c|}
\hline & $\begin{array}{l}\text { Men } \\
(n=58)\end{array}$ & $\begin{array}{l}\text { Women } \\
(n=150)\end{array}$ \\
\hline $\begin{array}{l}\text { Age in (years) (mean (SD)) } \\
\text { (range) }\end{array}$ & $\begin{array}{l}75 \cdot 6(9 \cdot 6) \\
60-95\end{array}$ & $\begin{array}{l}79 \cdot 5(8 \cdot 4) \\
61-100\end{array}$ \\
\hline $\begin{array}{l}\text { Commonest reason for institutional care (number and p } \\
\text { Cerebrovascular accident } \\
\text { Chronic lung diseases } \\
\text { Dementia } \\
\text { Musculoskeletal problems } \\
\text { Parkinson's disease } \\
\text { Blindness } \\
\text { "Old age" }\end{array}$ & $\begin{array}{l}31(53) \\
8(14) \\
3(5) \\
3(5) \\
2(3) \\
5(9)\end{array}$ & $\begin{array}{l}43(29) \\
13(9) \\
12(8) \\
3(2) \\
3(2) \\
6(4) \\
50(33)\end{array}$ \\
\hline $\begin{array}{l}\text { Commonest coexisting diagnoses (number and percenta } \\
\text { Hypertension } \\
\text { Chronic heart disease } \\
\text { Musculoskeletal problem } \\
\text { Neoplasm } \\
\text { Infection }\end{array}$ & $\begin{array}{c}10(17) \\
5(9) \\
3(5) \\
2(3) \\
4(7)\end{array}$ & $\begin{array}{c}22(15) \\
5(33) \\
7(5) \\
3(2) \\
4(3)\end{array}$ \\
\hline $\begin{array}{c}\text { Duration of stay in months (mean (SD)) } \\
\text { range }\end{array}$ & $\begin{array}{l}7 \cdot 0(11 \cdot 1) \\
<1 \text { to } 95\end{array}$ & $\begin{array}{l}28 \cdot 2(44 \cdot 5) \S \\
<1 \text { to } 240\end{array}$ \\
\hline $\begin{array}{l}\text { Functional ability* (number and percentage): } \\
\quad 1 \\
2 \\
3\end{array}$ & $\begin{array}{l}11(19) \\
10(17) \\
37(64)\end{array}$ & $\begin{array}{l}63(42) \ddagger \\
29(19) \\
58(39)\end{array}$ \\
\hline $\begin{array}{l}\text { Number of drugs taken (number of subjects and percent } \\
\text { None } \\
1 \\
2 \\
3 \\
4 \\
>4\end{array}$ & $\begin{array}{r}20(34) \\
6(10) \\
10(17) \\
8(14) \\
5(9) \\
9(16)\end{array}$ & $\begin{array}{l}68(45) \ddagger \\
25(17) \\
19(13) \\
14(9) \\
13(9) \\
11(7)\end{array}$ \\
\hline $\begin{array}{l}\text { Number }(\%) \text { taking vitamins or mineral supplements } \\
\text { Number }(\%) \text { self feeding: }\end{array}$ & $17(29)$ & $19(13) \ddagger$ \\
\hline $\begin{array}{l}\text { Yes } \\
\text { No }\end{array}$ & $\begin{array}{l}40(69) \\
18(31)\end{array}$ & $\begin{array}{c}123(82) \dagger \\
27(18)\end{array}$ \\
\hline
\end{tabular}

*1 Independent 2 Requires assistance 3 Bedridden.

Significant sex difference, $\chi^{2}$ test, $\nmid \mathrm{p}<0.05, \ddagger \mathrm{p}<0.001$. Student's $t$ test, $\S \mathrm{p}<0.0001$. 
been described elsewhere ${ }^{18}$; that of the water soluble vitamins, vitamin $A$ and $E$, and plasma proteins have also been described..$^{19-21}$

A follow up visit was made three months after the initial assessment to ascertain which subjects had died. Results were analysed by computer using the Statistical Analysis System (SAS). Fifty seven variables were examined. Student's $t$ test was used to compare values for subjects who had died with those still alive. Other methods used were stepwise regression analysis to examine the relative contributions of variables that showed a difference between the two groups, and discriminant function analysis was performed to develop a score that might distinguish between the two groups.

\section{Results}

Two hundred and eight subjects were examined, details of whom are shown in table 1. Cerebrovascular accident was the commonest cause for being put into care. The cause for admission was non-medical in 50 women $(33 \%)$, and was presumably due to social reasons. Hypertension and chronic heart disease were the commonest coexisting diagnoses, and over half of the 208 patients were taking drugs. Men had a shorter mean duration of stay and poorer functional ability, including ability to self-feed, compared with women. Three months after the survey had finished 12 men and 17 women had died. The mean (SD) age of those who died was $77.4(10.2)$ years, not significantly different from the mean age of those who were alive: $78.5(8.5)$ years. There was higher mortality among men: 12 of 58 $(21 \%)$ compared with women: 17 of $150(11 \%)$. The causes of death were listed as infection $(n=16)$, cardiorespiratory diseases $(n=6)$, cerebrovascular accident $(n=4)$, malignancy $(n=1)$, unclassified $(n=2)$. Because blood results were not complete in 17 subjects who died and for 28 who were alive, these subjects were excluded from the stepwise regression and discriminant function analysis.

Twenty eight out of 57 variables were significantly different at the $5 \%$ level between the two groups of survivors and non-survivors. Of these, 19 were significant at the $1 \%$ level (table 2). There was no difference in the type of diagnosis or drug use between the two groups, although as expected, the group that died had poorer functional ability. In 17 subjects that died not enough blood was available for all the tests. This was also true for 28 survivors.

A stepwise regression analysis was done based on the 19 variables shown in table 2 . Five variables were chosen in the order shown in table 3 , after which no other variables were selected. Fructosamine was the first variable chosen. Discriminant function analysis based on these five variables was performed using score of zero as the separation point between the two groups. The following equation was derived:

Score $=(9 \cdot 2 \times$ fructosamine $)+$

$(2.38 \times$ transferrin $)+(0.008 \times$ prealbumin $)-$

$(1.309 \times$ glycosylated haemoglobin $)-$

$(0.20 \times$ haemoglobin $)-6.029$

This score was calculated for all subjects and the distribution is shown in table 4 . The predicted outcome based on the score was compared with the actual outcome. Of 151 subjects who were alive, 146 had been predicted to survive, five to die; of the 12 who died, three should have survived according to the score. The sensitivity of the score for predicting short term mortality (death within three months) was $75 \%$, specificity $97 \%$, and predictive value $95 \%$.

Table 2 Variables that were significantly different $(p<0.01)$ in subjects who died compared with the rest

\begin{tabular}{|c|c|c|c|c|c|c|}
\hline & \multicolumn{3}{|l|}{ Died } & \multicolumn{3}{|c|}{ Survived } \\
\hline & Mean & $95 \% C I$ & $n=$ & Mean & $95 \% C I$ & $n=$ \\
\hline $\begin{array}{l}\text { Systolic blood pressure }(\mathrm{mm} \text { Hg) } \\
\text { Mid arm circumference }(\mathrm{cm}) \\
\text { Triceps skin fold }(\mathrm{mm}) \\
\text { Corrected arm muscle area }\left(\mathrm{cm}^{2}\right) \\
\text { Haemoglobin }(\mathrm{g} / \mathrm{dl}) \\
\text { Total white cell count }\left(\times 10^{9} / 1\right) \\
\% \text { neutrophils } \\
\text { Total protein }(\mathrm{g} / \mathrm{l}) \\
\text { Albumin }(\mathrm{g} / \mathrm{l}) \\
\text { Prealbumin }(\mathrm{mg} / \mathrm{l}) \\
\text { Fructosamine }(\mathrm{mmol} / \mathrm{l}) \\
\text { Transferrin }(\mathrm{g} / \mathrm{l}) \\
\text { Total thyoxine }(\mu \mathrm{mol} / \mathrm{l}) \\
\text { Cholesterol }(\mu \mathrm{mol} / \mathrm{l}) \\
\text { Albumin adjusted calcium }(\mu \mathrm{mol} / \mathrm{l}) \\
\text { Glycosylated haemoglobin }(\%) \\
\text { Plasma retinol }(\mathrm{mg} / 1) \\
\text { Plasma } B_{12}(\mathrm{pmol} / 1) \\
\text { Plasma zinc }(\mu \mathrm{mol} / \mathrm{l})\end{array}$ & $\begin{array}{c}136 * \\
20 \cdot 1^{* * *} \\
7 \cdot 0^{* *} \\
17 \cdot 8^{* *} \\
10 \cdot 8^{* *} \\
12 \cdot 1^{* * *} \\
76^{* * *} \\
68 \cdot 4^{* * *} \\
27 \cdot 5^{* * *} \\
131 \cdot 1^{* * *} \\
1 \cdot 45^{* * *} \\
1 \cdot 37^{* * *} \\
52 \cdot 7^{* * *} \\
3 \cdot 37^{* * *} \\
2 \cdot 49^{* * *} \\
8 \cdot 8^{* * *} \\
0 \cdot 28^{* * *} \\
552 \cdot 8^{* * *} \\
12 \cdot 0^{* * *}\end{array}$ & $\begin{array}{c}128-144 \\
18 \cdot 9-21 \cdot 3 \\
5 \cdot 6-8 \cdot 5 \\
15 \cdot 2-20 \cdot 4 \\
9 \cdot 8-11 \cdot 8 \\
10 \cdot 4-14 \cdot 8 \\
70-82 \\
64 \cdot 9-72 \cdot 0 \\
25 \cdot 4-29 \cdot 6 \\
98 \cdot 3-163 \cdot 9 \\
1 \cdot 37-1 \cdot 53 \\
1 \cdot 19-1 \cdot 55 \\
48 \cdot 4-57 \cdot 0 \\
3 \cdot 01-3 \cdot 73 \\
2 \cdot 41-2 \cdot 57 \\
6 \cdot 6-11 \cdot 1 \\
0 \cdot 20-0.36 \\
419 \cdot 4-686 \cdot 2 \\
10 \cdot 4-13 \cdot 6\end{array}$ & $\begin{array}{l}29 \\
29 \\
29 \\
29 \\
18 \\
18 \\
17 \\
19 \\
19 \\
16 \\
20 \\
16 \\
19 \\
15 \\
19 \\
19 \\
15 \\
19 \\
17\end{array}$ & $\begin{array}{c}147 \\
22 \cdot 7 \\
11 \cdot 1 \\
22 \cdot 5 \\
12 \cdot 2 \\
7 \cdot 5 \\
68 \cdot 0 \\
75 \cdot 2 \\
38 \cdot 0 \\
287 \cdot 8 \\
1 \cdot 85 \\
2 \cdot 07 \\
80 \cdot 7 \\
4 \cdot 71 \\
2 \cdot 31 \\
7 \cdot 2 \\
0.51 \\
351.4 \\
14 \cdot 4\end{array}$ & $\begin{array}{c}144-150 \\
22 \cdot 2-23 \cdot 2 \\
10 \cdot 0-12 \cdot 2 \\
21 \cdot 4-23 \cdot 6 \\
12 \cdot 0-12 \cdot 6 \\
7 \cdot 1-7 \cdot 9 \\
66-70 \\
74 \cdot 2-76 \cdot 2 \\
37 \cdot 2-38 \cdot 8 \\
278 \cdot 4-297 \cdot 2 \\
1 \cdot 82-1 \cdot 88 \\
2 \cdot 00-2 \cdot 14 \\
76 \cdot 8-84 \cdot 6 \\
4 \cdot 51-4 \cdot 91 \\
2 \cdot 28-2 \cdot 34 \\
7 \cdot 0-7 \cdot 4 \\
0 \cdot 47-0 \cdot 55 \\
317 \cdot 3-385 \cdot 5 \\
14 \cdot 0-14 \cdot 8\end{array}$ & $\begin{array}{l}178 \\
178 \\
179 \\
178 \\
178 \\
163 \\
148 \\
169 \\
167 \\
160 \\
172 \\
160 \\
157 \\
152 \\
167 \\
173 \\
149 \\
168 \\
152\end{array}$ \\
\hline
\end{tabular}

Significant difference between the two groups by Wilcoxon's rank sum test: ${ }^{*} p<0.01,{ }^{* *} p<0.005,{ }^{* * *} p<0.001$. 
Table 3 Stepwise regression analysis of variables in table 2

\begin{tabular}{rlll}
\hline & Variable & $\begin{array}{l}\text { Partial correlation } \\
\text { coefficient } r\end{array}$ & $p$ value \\
\hline Step 1 & Fructosamine & 0.25 & 0.0001 \\
2 & Transferrin & 0.07 & 0.01 \\
3 & Glycosylated & 0.04 & 0.04 \\
& haemoglobin & 0.04 & 0.04 \\
4 & Prealbumin & 0.04 & 0.05 \\
5 & Haemoglobin & 0.03 & \\
\hline
\end{tabular}

\section{Discussion}

There is little information on the nutritional state of residents of long term care institutions in Asian countries. Malnutrition, particularly protein calorie malnutrition, is likely to be a common problem. Due to the lack of medical and nursing staff in some chronic care institutions in Hong Kong the nutritional aspect of care tends to be neglected. Compared with elderly subjects leading an active life in the community, the elderly in institutions have lower arm muscle circumference, corrected arm muscle area, plasma proteins, thiamine, cyanocobalamin, folic acid, and ascorbic acid concentrations ( $\mathrm{J}$ Woo, unpublished observations). Because protein calorie malnutrition predisposes to mortality, ${ }^{8}$ it is not surprising that three of the variables in the discriminant function for predicting mortality have been previously described as markers of protein calorie malnutritiontransferrin, prealbumin, ${ }^{6}$ and haemoglobin. ${ }^{22}$

Unlike previous studies on surgical patients, ${ }^{9-11}$ arm anthropometric measurements did not contribute to the prediction of mortality, even though they were lower in those who died. The results agree with other studies of geriatric populations ${ }^{712}$ and in patients from all sources. ${ }^{14}$ Surprisingly, unlike other studies of geriatric or surgical patients, albumin was not a predictor of mortality, and only prealbumin and transferrin contributed to predictions of outcome. In a study of 176 men in a nursing home Rudman et al found that cholesterol was the most important pre-

Table 4 Distribution of discriminant function score among subjects alive and those who had died within three months

\begin{tabular}{cll}
\hline & \multicolumn{2}{l}{ No of subjects } \\
\cline { 2 - 3 } Score & Alive at 3 months & Dead at 3 months \\
\hline-5.0 & 0 & 2 \\
-2.5 & 2 & 5 \\
0 & 3 & 3 \\
2.5 & 15 & 2 \\
5.0 & 55 & 0 \\
7.5 & 50 & 0 \\
10.0 & 21 & 0 \\
12.5 & 5 & 0 \\
\hline
\end{tabular}

*A negative score represents increased likelihood of dying within three months. dictor, followed by haematocrit. ${ }^{1323}$ In our study, although mean cholesterol concentration was lower in those who died, it did not contribute to prediction of outcome. Haemoglobin, however, was a significant predictor. The difference may be explained by the exclusion of women and the lower prevalence of subjects with physiological illness in their study.

Fructosamine and glycosylated haemoglobin concentrations have not been examined in institutionalised geriatric subjects before, most studies using these measurements as an assessment of hyperglycaemia. ${ }^{24-25}$ These measurements were included in our study as we were interested in the prevalence of diabetes mellitus in the local population. Surprisingly, both variables were chosen as discriminating variables. Fructosamine is a measure of serum glycosylproteins and would be low in protein calorie malnutrition when the concentration of plasma proteins fall. Estimation of fructosamine, therefore, seems to be another sensitive index of malnutrition, comparable with measurement of single proteins such as prealbumin and transferrin, with the added advantage of being cheap. The explanation for the higher percentage of glycosylated haemoglobin among those that died is uncertain. The higher values may have been due to the presence of renal failure or impaired glucose tolerance, ${ }^{18}$ which occur shortly before death. The former is unlikely because there was no difference in urea or creatinine concentrations between the two groups.

Among the other variables not chosen as predictors, but which were significantly different between survivors and non-survivors, there were some interesting findings. Mean systolic blood pressure was lower in those who died, which supports the finding in a recent study that there is increased mortality in the lowest blood pressure groups among the very old. ${ }^{26}$ The presence of infection with possible septicaemic shock may have contributed to the low blood pressure in some cases, but this is unlikely as there was no difference in diastolic blood pressure. The higher total white cell count and percentage of neutrophils among those who died is a reflection of the presence of infection, a common cause of death among this population. The higher plasma calcium (albumin adjusted) concentration in those who died probably reflects poorer functional mobility in this group. Plasma calcium was found to be significantly higher among bedridden subjects compared with others in this survey $(2.37 \mathrm{mmol} / \mathrm{l}(\mathrm{SD} 0.13), \mathrm{n}=83, v 2.27$ $\mathrm{mmol} / \mathrm{l}(0.40), \mathrm{n}=103 ; \mathrm{p}<0.05)$. In this study neither proteinuria nor increased plasma urea were found to be predictors of mortality. Although the mean urea concentration was higher among those who died (10.3 $\mathrm{mmol} / \mathrm{l}(5 \cdot 6), \mathrm{n}=19)$ compared with those who were alive $(7.5 \mathrm{mmol} / \mathrm{l}(4.5), \mathrm{n}=171)$, the difference just reached significance at the $5 \%$ level by Wilcoxon's 
rank sum test and did not contribute to prediction of outcome. Some factors may have been missed due to the small numbers studied. Predictors of short term mortality may also be slightly different from those predicting mortality at the end of a longer period-for example, after one year.

This survey shows that subjects who died within three months have evidence of poorer nutritional state compared with those who remained alive at three months. They had protein calorie malnutrition, shown by lower arm anthroprometric measurements, total plasma protein, albumin, prealbumin, and transferrin and haemoglobin concentrations, as well as low plasma retinol and zinc concentrations. The discriminant function score was useful for identifying patients who had a high risk of death within three months and for whom nutritional support may have been beneficial. It could be argued that the lives of demented, bedridden patients in chronic care should not be prolonged in this way, analogous to the withholding of antibiotics to treat infections in such patients. Nevertheless, the score may also be applicable to patients in general medical wards, and the discriminant function score may be tested in such patients in the near future.

We thank Hoffmann-La Roche, Basel, Switzerland, for a financial contribution towards the laboratory tests.

\section{References}

1 Cashman MD. Geriatric malnutrition. Recognition and correction. Postgrad Med J 1982;71:185-94.

2 Arora VD, Rudman D. Protein-calorie undernutrition in the nursing home. Geriatric Medicine Today 1988;7:66-75.

3 Baker H, Frank O, Thind IS, Jaslow SP, Louria DB. Vitamin profiles in elderly persons living at home or in nursing homes, versus profile in healthy young subjects. J Am Geriatr Soc 1979;27:444-50.

4 Ingenbleek Y, Van Den Schrieck H-G, De Nayer P, De Visscher $M$. Albumin, transferrin and the thyroxine-binding prealbumin/retinol-binding protein (TBPA-RBP) complex in assessment of malnutrition. Clin Chim Acta 1975;63:61-7.

5 Sachs E, Bernstein LH. Protein markers of nutrition status as related to sex and age. Clin Chem 1986;32:339-41.

6 Hadier M, Haider SQ. Assessment of protein-calorie malnutrition. Clin Chem 1984;30:1286-99.

7 Kergoat M-J. Leclerc BS, PetitClerc C, Imbach A. Discriminant biochemical markers for evaluating the nutritional status of elderly patients in long-term care. Am J Clin Nutr 1987;46: 849-61.

8 Biena R, Ratcliff S, Barbour GL, Kummer M. Malnutrition in the hospitalized geriatric patient. J Am Geriatr Soc 1982;30:433-6.
9 Mullen JL, Buzby GP, Waldman MT, Gertner MH, Hobbs CL, Rosato EF. Prediction of operative morbidity and mortality by preoperative nutritional assessment. Surg Forum 1979;30:80-2.

10 Dempsey DT, Busby GP, Mullen JL. Nutritional assessment in the seriously ill patient. J Am Coll Nutr 1983;2:15-23.

11 Rainey-MacDonald CG, Holliday RL, Wells GA, Donner AP. Validity of a two-variable nutritional index for use in selecting candidates for nutritional support. J Parent Ent Nutr 1983;7: 15-20.

12 Rudman D, Feller AG, Nagraj HS, Jackson DL, Rudman IW, Mattson DE. Relation of serum albumin concentration to death rate in nursing home men. $J$ Parent Ent Nutr 1987;11:360-3.

13 Rudman D, Mattson DE, Nagraj HS, Caindec N, Rudman IW, Jackson DL. Antecedents of death in the men of a veterans administration nursing home. J Am Geriatr Soc 1987;35: 496-502.

14 Harvey KB, Moldawer LL, Bistrian BR, Blackburn GL. Biological measures for the formulation of a hospital prognostic index. Am J Clin Nutr 1981;34:2013-22.

15 MacDonald D, Swaminathan R. Seasonal variations in 25 hydroxyvitamin D in plasma of Hong Kong Chinese. Clin Chem 1988;34:2375.

16 Payne RB, Little AJ, Williams RB, Milner JR. Interpretation of serum calcium in patients with abnormal serum proteins. $\mathrm{Br}$ Med J 1973;4:643-6.

17 Pesce AJ, Kaplan LA. Methods in clinical chemistry. St Louis, Missouri: CV Mosby, 1987.

18 Woo J, Swaminathan R, Cockram C, et al. The prevalence of diabetes mellitus and an assessment of methods of detection among a community of elderly Chinese in Hong Kong. Diabetologia 1987;30:863-8.

19 Woo J, Ho SC, Mak YT, et al. Nutritional status of the watersoluble vitamins in an active Chinese elderly population in Hong Kong. Eur J Clin Nutr 1988;42:415-24.

20 Woo J, Ho S, Mak YT, Shek CC, Swaminathan R. Vitamin A and E status in healthy elderly Chinese in Hong Kong. Eur J Clin Nutr 1988;42:689-95.

21 Woo J, Cheung CK, Ho SC, Mak YT, Swaminathan R. Protein nutritional status in elderly Chinese in Hong Kong. Eur J Clin Nutr 1988;42:903-9.

22 Lipschitz DA. Nutrition, aging, and the immunohematopoietic system. In: Watkin DM, ed. Nutrition in older persons. Clinics in Geriatric Medicine. Philadelphia: WB Saunders Co, 1987: 319-28.

23 Rudman D, Mattson DE, Nagraj HS, et al. Prognostic significance of serum cholesterol in nursing home men. J Parent Ent Nutr 1988;12:155-8.

24 Johnson RN, Metcalf PA, Baker JR. Fructosamine: a new approach to the estimation of serum glycosylprotein. An index of diabetic control. Clin Chim Acta 1982;127:87-95.

25 Graf RJ, Halter JB, Porte D. Glycosylated hemoglobin in normal subjects and subjects with maturity-onset diabetes. Diabetes 1979;27:834-9.

26 Mattila K, Haavisto M, Rajala S, Heikinheimo R. Blood pressure and five year survival in very old. $\mathrm{Br}$ Med J 1988;296:887-9.

Requests for reprints to: $\mathrm{Dr}$ Jean Woo, Department of Medicine, Prince of Wales Hospital, Shatin, NT, Hong Kong. 